\title{
PRESUPOSISI PADA BAHASA SPANDUK IKLAN WARUNG BAKSO DI BALIKPAPAN
}

\author{
Lutfi Ika Sari ${ }^{1}$, Retnowaty ${ }^{2}$, Ari Musdolifah ${ }^{3}$ \\ Universitas Balikpapan ${ }^{1}$, Universitas Balikpapan², Universitas Balikpapan ${ }^{3}$ \\ pos-el: lutfiikasari95@gmail.com¹, Retnowaty@uniba-bpn.ac.id², Arymusdolifah@uniba-bpn.ac.id ${ }^{3}$
}

\begin{abstract}
ABSTRAK
Penelitian ini bertujuan untuk mendeskripsikan wujud presuposisi Bahasa spanduk iklan warung bakso di Balikpapan, khususnya pada kecamatan Balikpapan utara. Penelitian ini menggunakan jenis penelitian kualitatif. Data yang digunakan dalam penelitian ini adalah kata-kata, frase, dan kalimat yang mengandung preuposisi dalam spanduk iklan warung bakso di Balikpapan, yang dikaji dari segi pragmatik. Sumber data pada penelitian ini adalah spanduk iklan warung bakso di Balikpapan, khususnya kecamatan Balikpapam utara. Pengumpulan data dilakukan dengan menggunakan teknik dokumen. Instrumen penelitian yang digunakan adalah peneliti sendiri (human instrumen), dibantu dengan kamera handphone, dan kartu data. Penelitian ini disusun dan dilaksanakan dengan menggunakan model analisis data kualitatif menurut Miles dan Huberman, meliputi reduksi data, sajian data, dan simpulan. Teknik analisis penelitian yang digunakan adalah teknik agih. Hasil analisis pada penelitian ini, ditemukan 38 data dengan empat jenis presuposisi, yaitu 20 data presuposisi eksistensial, 11 data presuposisi faktif, 5 presuposisi leksikal, dan 2 presuposisi struktural. Presuposisi eksistensial banyak digunakan karena pada bahasa spanduk iklan tersebut, tidak hanya menjelaskan satu maksud tetapi lebih luas lagi dengan menggunakan kata-kata yang menarik pembaca. Sehingga sebagai daya tarik pengunjung yang ingin tahu atau penasaran, untuk membeli bakso yang ditawarkan.
\end{abstract}

Kata kunci presuposisi, spanduk iklan warung bakso

\section{ABSTRACT}

This study aims to describe the form of presupposition Language banner advertising stalls meatballs in Balikpapan, especially in the district of northern Balikpapan. This research uses qualitative research type. The data used in this study are words, phrases, and sentences containing preuposition in the banner of a meatball stall in Balikpapan, which is studied in terms of pragmatics. Data source in this research is banner of advertising of meatball stalls in Balikpapan, especially sub district of Balikpapam. Data collection is done by using document technique. The research instrument used is the researcher himself (human instrument), assisted by camera phone, and data card. This study was prepared and implemented using qualitative data analysis model according to Miles and Huberman, including data reduction, data presentation, and conclusion. Technique of research analysis used is technique of agih. The results of the analysis in this study, found 38 data with four types of presupposition, namely 20 existential presupposition data, 11 data factive presuposisi, 5 lexical presuposisi, and 2 structural presuposisi. Existential presuppositions are widely used because in the ad banner language, it not only explains one purpose but more broadly by using words that appeal to the reader. So as the attraction of curious visitors or curious, to buy meatballs on offer.

Keywords: Presupposition, Meatball stall advertising banner

\section{PENDAHULUAN}

Istilah-istilah unik memiliki makna bentuk atau jenis yang berbeda dari yang lain. Oleh sebab itu, tidak ada persamaan makna atau jenis dengan yang lain. Jika, setiap orang melihat atau mendengar istilah-istilah unik, pasti orang tersebut akan memiliki anggapan yang bermacam- macam. Setiap orang juga beranggapan bahwa istilah-istilah tersebut memiliki ciri khas yang spesifik dan tidak dimiliki oleh orang lain.

Istilah unik biasanya digunakan untuk menarik perhatian agar orang lain penasaran dengan istilah tersebut. Saat ini istilah-istilah unik banyak digunakan di 
berbagai tempat, misalnya pada spanduk iklan warung makan. Hal tersebut digunakan untuk menarik perhatian agar orang-orang tertarik untuk datang. Sebelum orang tersebut benar-benar tahu dan memahami makna dari istilah-istilah unik tersebut, mereka pasti memiliki praanggapan yang berbeda-beda. Praanggapan tersebut ditujukan untuk istilah-istilah yang jarang mereka dengar atau ketahui sebelumnya.

Kata praanggapan atau anggapan dasar, dalam ilmu pragmatik biasa disebut dengan presuposisi. Presuposisi berasal dari kata to pre-suppose, yang dalam bahasa inggris berarti to suppose beforehand, yang berarti menduga sebelumnya. Menurut Yule (2006: 33) presuposisi atau praanggapan merupakan sesuatu yang diasumsikan oleh penutur sebagai kasus atau kejadian sebelum menghasilkan suatu ujaran atau tuturan. Asumsi-asumsi tersebut muncul karena penutur belum mengetahui maksud yang sebenarnya, misalnya saja pada spanduk iklan warung.

Setelah melihat spanduk iklan warung makan yang ada di Balikpapan, peneliti tertarik meneliti spanduk iklan warung makan yang unik. Spanduk iklan warung makan tersebut menggunakan nama-nama yang unik sebagai daya tarik pengunjung untuk membeli dagangan yang ditawarkan. Ketika pengunjung melihat spanduk iklan warung makan tersebut, mereka akan memiliki anggapan yang bermacam-macam, misalnya, pada spanduk iklan warung bakso "Bakso Lek Min”, para pengunjung ataupun orang yang hanya sekedar lewat pasti memiliki berbagai macam anggapan. Spanduk iklan warung makan "Bakso Lek Min" menunjukkan bahwa warung tersebut menyediakan bakso, di warung tersebut hanya menyediakan satu jenis makanan yaitu bakso, warung tersebut milik lek Min, jika pengunjung membeli bakso di warung tersebut pengunjung harus memanggil penjualnya dengan sebutan lek, lek Min adalah nama seorang laki-laki, biasanya orang yang dipanggil lek adalah bapak-bapak, dan lain sebagainya.

Berkaitan dengan hal tersebut, peneliti didukung dengan penelitian yang relevan. Penelitian relevan dilakukan oleh Jumi Larasati (2015), dengan judul "Analisis Presuposisi pada Bahasa Spanduk Iklan Warung Soto: Kajian Pragmatik". Penelitian milik Jumi Larasati ini, meneliti kajian pragmatik mengenai analisis presuposisi pada bahasa spanduk iklan warung soto. Dari penelitian ini, terdapat enam tipe presuposisi (praanggapan), yaitu presuposisi eksistensial, presuposisi faktif, presuposisi leksikal, presuposisi nonfaktif, presuposisi struktural, dan presuposisi kontrafaktual. Dari 40 data warung soto yang telah dianalisis peneliti, terdapat 21 data presuposisi esistensial, 20 data presuposisi non-faktif, dan 3 data presuposisi struktural. Dari penelitian milik Jumi Larasati, peneliti ingin mengetahui praanggapan atau presuposisi pada spanduk iklan warung makan, khususnya warung bakso yang terdapat di kota Balikpapan.

Berdasarkan latar belakang tersebut, peneliti memilih judul "Presuposisi pada Bahasa Spanduk Iklan Warung Bakso di Balikpapan". Judul tersebut diambil, karena peneliti melihat bahasa spanduk iklan warung bakso unik yang terdapat di kota Balikpapan. Sehingga peneliti berpikir, dengan bahasa spanduk iklan warung bakso yang unik tersebut, banyak orang ataupun pengunjung yang memiliki berbagai macam anggapan ketika pertama kali melihat spanduk iklan warung makan tersebut.

\section{Presuposisi}

Presuposisi atau praanggapan berasal dari kata to pre-suppose, yang dalam bahasa Inggris berarti to suppose beforehand (menduga sebelumnya atau dugaan sementara), dalam arti sebelum pembicara atau penulis mengujarkan sesuatu ia sudah memiliki dugaan sebelumnya tentang lawan bicara atau yang dibicarakan. Presuposisi 
(praanggapan) merupakan suatu pengalaman manusia sehari-hari.

Nababan (1987) memberikan pengertian bahwa praanggapan adalah dasar atau penyimpulan dasar mengenai konteks dan situasi berbahasa (menggunakan bahasa) yang membuat bentuk bahasa (kalimat atau ungkapan) mempunyai makna bagi pendengar atau penerima bahasa itu dan sebaliknya. Sehingga, dapat membantu pembicara menentukan bentuk-bentuk bahasa yang dapat dipakainya untuk mengungkapkan makna atau pesan yang dimaksud.

Menurut Yule (2006) presuposisi atau praanggapan merupakan sesuatu yang diasumsikan oleh penutur sebagai kasus atau kejadian sebelum menghasilkan suatu ujaran atau tuturan. Dalam hal ini, yang memiliki presuposisi atau praanggapan adalah penutur bukan kalimat.

Yule (2006) menyatakan bahwa terdapat 6 jenis presuposisi (praanggapan), sebagai berikut:

\section{1) Presuposisi Eksistensial}

Presuposisi eksistensial merupakan asumsi bahwa seseorang atau sesuatu, yang diidentifikasi dengan menggunakan frasa kata benda, benar-benar ada. Presuposisi eksistensial tidak hanya menjelaskan satu maksud, tetapi menjelaskan suatu maksud dengan lebih luas lagi.

Contoh:

a. Orang itu berjalan. (Ada orang yang berjalan).

b. Perempuan itu melangkah. (Ada perempuan melangkah).

2) Presuposisi Faktif

Presuposisi faktif yaitu presuposisi (praanggapan) bahwa informasi yang dinyatakan setelah kata-kata tertentu adalah benar. Biasanya, informasi yang dipraanggapkan mengikuti kata kerja, sehingga dapat dianggap sebagai kenyataan.

Contoh: a. Dia tidak menyadari bahwa ia terluka. (Dia terluka).

b. Kami menyesal datang ke rumahnya. (Kami datang ke rumahnya).

\section{3) Presuposisi Leksikal}

Presuposisi leksikal yaitu presuposisi (praanggapan) yang menggunakan satu kata, penutur dapat bertindak seolah-olah makna (kata) yang lain akan dipahami. Sehingga, pada presuposisi leksikal suatu kata dapat menimbulkan makna kata lainnya.

Contoh:

a. Dia berhenti merokok. (Dulu dia biasa merokok).

b. Mereka mulai mengeluh. (Sebelumnya mereka tidak mengeluh).

\section{4) Presuposisi Non-Faktif}

Presuposisi non-faktif yaitu presuposisi (praanggapan) bahwa informasi tertentu, sebagaimana yang disajikan tidak benar. Presuposisi ini menimbulkan makna-makna yang kebenarannya masih perlu dipertanyakan (ambigu).

Contoh:

a. Saya membayangkan bahwa saya berada di Korea. (Saya tidak berada di Korea).

b. Kalau saya memiliki banyak perusahaan. (Saya tidak memiliki banyak perusahaan).

\section{5) Presuposisi Struktural}

Presuposisi struktural yaitu presuposisi (praanggapan) yang menyatakan bahwa bagian suatu struktur mengandung informasi yang dianggap telah diketahui. Struktur kalimat tertentu telah dianalisis sebagai praanggapan secara tetap bahwa bagian struktur itu diasumsikan kebenarannya dan mudah dipahami. Hal ini terdapat dalam kalimat tanya sesudah diketahui sebagai suatu masalah. 
Contoh:
a. Di mana anda membeli sepeda itu? (Anda membeli sepeda).
b. Kapan dia datang? (Dia datang).

6) Presuposisi Kontrafaktual

Presuposisi kontrafaktual yaitu

presuposisi (praanggapan) yang menyatakan bahwa informasi tertentu lawan dari yang sebenarnya. Hal tersebut menunjukan bahwa yang dipraanggapkan tidak hanya tidak benar, tetapi juga merupakan kebalikan dari benar atau bertolak belakang dengan kenyataan.

Contoh:

a. Seandainya Ibu kota Kalimantan Timur ada di Balikpapan. (Ibu kota Kalimantan Timur bukan di Balikpapan).

b. Kalau saja lelaki dapat hamil, mungkin lelaki bisa mengetahui sakitnya. (Lelaki tidak dapat hamil dan tidak mungkin bisa mengetahui sakitnya).

\section{Iklan}

Djaya kusumah (Pujiyanto, 2013) berpendapat bahwa iklan merupakan suatu lukisan-lukisan, tulisan, sebagai media komunikasi yang merupakan wakil atau gambaran hasil produk seseorang, yang memerlukan biaya untuk mempromosikan hasil produksinya melalui iklan dengan maksud untuk memengaruhi suatu tujuan di bidang perdagangan baik perusahaanperusahaan maupun pemakai produk, sehingga mereka merasa tertarik dan senang dengan produk tersebut. Hal tersebut bertujuan agar konsumen dapat terpengaruh untuk membeli produk atau jasa yang ditawarkan dari iklan tersebut.

Iklan dibuat untuk memberi informasi dan membujuk para konsumen untuk mencoba atau mengikuti suatu produk atau jasa yang ditawarkan. Iklan juga bertujuan meyakinkan konsumen akan kebenaran dari produk atau jasa yang ditawarkan agar konsumen tertarik untuk memiliki atau menggunakan produk atau jasa yang ditawarkan oleh iklan tersebut.
Biasanya, iklan yang ditawarkan kepada khalayak ramai, dipasang di media massa atau di tempat umum. Pada media massa biasanya terdapat pada surat kabar, majalah, dan lain sebagainya. Sedangkan, pada tempat umum, biasanya terdapat pada poster, baliho, spanduk, dan lain sebagainya.

Spanduk yang merupakan kain rentang yang berisi slogan, propaganda, atau berita yang diketahui umum (KBBI). Spanduk menjadi pilihan media promosi yang cukup populer, karena biasanya berisi informasi singkat mengenai suatu produk atau peringatan umum, yang di pajang di tepi jalan atau melintang di tengah jalan sehingga dapat dibaca oleh pengguna jalan yang melewatinya. Melalui spanduk, pedagang juga dapat menampilkan gambar sekaligus informasi yang dapat menunjang minat pembeli atau konsumen agar dapat menumbuhkan kepercayaan orang banyak terhadap produk yang di tawarkan.

\section{METODE PENELITIAN}

Penelitian ini menggunakan jenis penelitian kualitatif. Sumber data pada penelitian ini adalah spanduk iklan warung bakso di Balikpapan, khususnya kecamatan Balikpapam utara. Instrumen dalam penelitian ini adalah peneliti sendiri (human instrumen). Instrumen lainnya berupa kamera handphone Asus Zenfone 2 Laser berwarna putih serta kartu data. Dalam Penelitian ini peneliti menggunakan teknik dokumen. Adapun teknik yang digunakan dalam pemeriksaan keabsahan data adalah teknik triangulasi. Teknik analisis penelitian yang digunakan adalah teknik agih.

Penelitian ini disusun dan dilaksanakan dengan menggunakan model analisis data kualitatif menurut Miles dan Huberman. Miles dan Huberman (Sugiyono, 2012) mengemukakan bahwa langkah- langkah dalam analisis data kualitatif dilakukan secara interaktif dan berlangsung secara terus menerus sampai tuntas, sehingga datanya sudah 
jenuh. Ukuran kejenuhan data ditandai dengan tidak diperolehnya lagi data. Langkah-langkah dalam analisis data meliputi reduksi data (data reduction), sajian data (data display), dan simpulan (conclusion drawing/verification).

\section{HASIL DAN PEMBAHASAN}

Berdasarkan penelitian yang telah dilakukan, pada bab ini akan disajikan analisis penelitian dan pembahasan mengenai presuposisi pada bahasa spanduk iklan warung bakso di Balikpapan. Selain itu akan menyajikan hasil penelitian berupa analisis dalam bentuk tabel beserta penjelasannya, kemudian hasil penelitian tersebut akan dideskripsikan dalam pembahasan.

a. Presuposisi Eksistensial

Presuposisi eksistensial dapat dilihat pada bahasa spanduk iklan warung bakso di bawah ini.

Bakso, Bakwan, dan Mie Ayam "Pelangi" (D1/1.E)

Spanduk di atas bertujuan sebagai daya tarik pengunjung untuk membeli mie ayam dan bakso yang ditawarkan. Spanduk iklan yang terdapat di wilayah kecamatan Balikpapan utara, tepatnya di strart 3 dengan kalimat "Bakso, Bakwan, dan Mie Ayam Pelangi" ini merupakan jenis kalimat presuposisi. Hal tersebut dapat dilihat dari hasil presuposisi, yang menunjukkan jika ada warung yang menjual tiga jenis makanan, yaitu bakso, bakwan, dan mie ayam.

Warung bakso, bakwan, dan mie ayam tersebut memiliki nama pelangi. Kata pelangi merupakan presuposisi eksistensial, karena kata pelangi memiliki makna yang tidak hanya menjelaskan satu maksud, tetapi menjelaskan maksud lainnya secara luas. Jika pembaca belum mengetahui kebenarannya, kemungkinan pembaca beranggapan jika bakso, bakwan, dan mie ayam yang dijual memiliki warna seperti pelangi. Kemungkinan lain adalah warung, meja, kursi, dan peralatan yang digunakan memiliki warna seperti pelangi.

Sehingga dari beberapa kemungkinan di atas, ditemukan hasil presuposisi mungkin terjadi pada data (D1/1.E) adalah jenis presuposisi eksistensial. Hasil presuposisi tidak hanya melihat jika tempat makan tersebut menjual bakso, bakwan, dan mie ayam tetapi memiliki makna yang lebih luas lagi, seperti apa saja jenis bakso yang dijual dan makna dari kata pelangi. Oleh sebab itu, dapat dikatakan bahwa spanduk iklan di atas menghasilkan jenis presuposisi eksistensial.

\section{b. Presuposisi Faktif}

Presuposisi faktif dapat dilihat pada bahasa spanduk iklan warung bakso di bawah ini.

Mie Ayam dan Bakso Solo Pak Gito (D2/l.F)

Spanduk iklan yang terdapat di wilayah kecamatan Balikpapan utara, dengan kalimat "Mie Ayam dan Bakso Solo Pak Gito" ini merupakan jenis kalimat presuposisi. Hal tersebut dapat dilihat dari hasil presuposisi, yang menunjukkan jika ada warung yang menjual dua jenis makanan, yaitu mie ayam dan bakso.

Mie ayam dan bakso tersebut resepnya dari kota Solo. Sehingga, rasa dan kualitasnya sama seperti mie ayam dan bakso yang ada di kota Solo. Bagi pembaca yang baru pertama kali membaca kalimat spanduk iklan tersebut, kemungkinan akan beranggapan jika di warung tersebut ada orang yang memiliki nama Pak Gito. Kemungkinan lain, pembaca akan beranggapan jika warung tersebut adalah milik Pak Gito, yang kita anggap jika seseorang dipanggil Pak, maka orang tersebut adalah seorang laki-laki atau bapak-bapak. Pembaca pun akan beranggapan jika Pak Gito adalah orang yang telah membuat bakso tersebut (koki). Sehingga, dari data (D2/1.F) 
ditemukan hasil presuposisi yang mungkin terjadi pada seseorang yang melihat dan membaca bahasa spanduk iklan warung bakso tersebut. Hasil presuposisi yang terjadi sudah benar adanya, karena dapat dilihat dari kata-kata sebelumnya yang sudah menjelaskan bahwa diwarung Pak Gito tersebut menjual mie ayam dan bakso Solo. Oleh sebab itu, dapat dikatakan bahwa spanduk iklan di atas menghasilkan jenis presuposisi faktif.

\section{c. Presuposisi Leksikal}

Presuposisi leksikal dapat dilihat pada bahasa spanduk iklan warung bakso di bawah ini.

\section{Bakso Gendong (D3/2.L)}

Spanduk iklan yang terdapat di wilayah kecamatan Balikpapan utara, tepatnya di KM 5 dengan kalimat "Bakso Gendong" ini merupakan jenis kalimat presuposisi. Hal tersebut dapat dilihat dari hasil presuposisi, yang menunjukkan jika ada warung yang menjual makanan, yaitu bakso.

Bagi pembaca yang melihat spanduk iklan tersebut, akan beranggapan jika bakso tersebut dijual dengan digendong. Anggapan lainnya bakso yang dijual, ukurannya sangat besar, sehingga ketika diangkat harus digendong.

Dari hasil presuposisi di atas, jenis presuposisi yang mungkin terjadi pada data (D3/2.L) adalah jenis presuposisi leksikal. Presuposisi leksikal yaitu presuposisi yang menggunakan satu kata, penutur dapat bertindak seolah-olah makna (kata) yang lain akan dipahami. Sehingga, dari data di atas ditemukan hasil presuposisi yang mungkin terjadi pada seseorang yang melihat dan membaca bahasa spanduk iklan tempat makan bakso tersebut. Pada data ini, bahasa yang digunakan dapat menimbulkan makna kata lain yang akan dipahami oleh pembaca, seperti pada kata "Gendong". Oleh sebab itu, dapat dikatakan bahwa spanduk iklan di atas menghasilkan jenis presuposisi leksikal.

\section{d. Presuposisi Struktural}

Presuposisi struktural dapat dilihat pada bahasa spanduk iklan warung bakso di bawah ini.

Bakso Solo dan Mie Ayam Graha Indah (D4/1.S)

Spanduk iklan yang terdapat di wilayah kecamatan Balikpapan utara, dengan kalimat "Bakso Solo dan Mie Ayam Graha Indah" ini merupakan jenis kalimat presuposisi. Hal tersebut dapat dilihat dari hasil presuposisi, yang menunjukkan jika ada warung yang menjual dua jenis makanan, yaitu bakso dan mie ayam.

Bagi pembaca yang baru pertama kali membaca kalimat spanduk iklan tersebut, kemungkinan akan beranggapan jika kalimat tersebut menunjukkan, jika bakso tersebut resepnya dari kota Solo. Sehingga, rasa dan kualitasnya sama seperti bakso yang ada di kota Solo, tetapi tidak untuk mie ayam. Selain itu, pembaca juga beranggapan jika warung tersebut diberi nama "Bakso Solo dan Mie Ayam Graha Indah" karena bakso dan mie ayam tersebut terdapat di daerah Graha Indah.

Dari hasil presuposisi di atas, jenis presuposisi yang mungkin terjadi pada data (D4/1.S) adalah jenis presuposisi struktural. Presuposisi struktural merupakan presuposisi yang menyatakan bahwa bagian suatu struktur mengandung informasi yang dianngap telah diketahui. Sehingga, dari data di atas ditemukan hasil presuposisi yang mungkin terjadi pada seseorang yang melihat dan membaca bahasa spanduk iklan tempat makan bakso tersebut. Pada data ini, kebenaran dari bahasa spanduk iklan bakso tersebut sudah terbukti. Bahasa spanduk menjelaskan di daerah Graha Indah, terdapat penjual bakso Solo dan mie ayam. Sehingga dari penggunaan bahasanya yang sederhana, konsumen dapat 
mengerti maksud dari bahasa spanduk iklan tersebut. Oleh sebab itu, dapat dikatakan bahwa spanduk iklan di atas menghasilkan jenis presuposisi struktural.

Berdasarkan hasil penelitian yang telah dianalisis dapat disimpulkan bahwa ditemukan empat jenis presuposisi pada bahasa spanduk iklan warung bakso di Balikpapan, yaitu presuposisi eksistensial, presuposisi faktif, presuposisi leksikal, dan presuposisi struktural. Penelitian ini dikhususkan di wilayah kecamatan Balikpapan utara, karena kecamatan Balikpapan utara memiliki wilayah yang paling luas dibandingkan kecamatankecamatan lainnya dan cenderung memiliki jumlah tempat makan bakso yang lebih banyak dibandingkan kecamatan-kecamatan lainnya.

Berdasarkan hasil penelitian ditemukan 38 data bahasa spanduk iklan warung bakso yang memiliki presuposisi. Presuposisi eksitensial memiliki data yang paling banyak, yaitu 20 data. Presuposisi ini banyak digunakan karena pada bahasa spanduk iklan tersebut, tidak hanya menjelaskan satu maksud tetapi lebih luas lagi dengan menggunakan kata- kata yang menarik pembaca. Sehingga sebagai daya tarik pengunjung yang ingin tahu atau penasaran, untuk membeli bakso yang ditawarkan.

Analisis data pada presuposisi faktif juga banyak ditemukan, yakni 11 data. Karena pada presuposisi ini informasi yang dinyatakan setelah kata-kata tertentu sudah jelas kebenarannya.

Pada presuposisi leksikal memiliki 5 data. Presuposisi ini merupakan presuposisi yang menggunakan satu kata, penutur dapat bertindak seolah-olah makna (kata) yang lain akan dipahami. Analisis data yang paling sedikit adalah presuposisi struktural dengan 2 data. Data ini paling sedikit karena bahasa dari spanduk iklan tersebut sangat mudah dipahami, dengan kata-kata yang mudah, sehingga kurang menarik pembaca.

\section{KESIMPULAN}

Pada bahasa spanduk iklan warung bakso didapatkan banyak praanggapan yang terjadi. Beberapa praanggapan yang terjadi pada satu tuturan atau tulisan tidak bisa ditemukan jumlahnya. Karena suatu tuturan atau tulisan akan memiliki makna dan praanggapan yang berbeda dari satu orang dengan orang lainnya. Sehingga, hal tersebut tergantung wawasan, pengalaman, dan sudut pandang orang yang membaca kemudian mempraaggapkan bahasa spanduk iklan warung bakso tersebut.

\section{DAFTAR PUSTAKA}

Nababan, P. W. J. (1987). Ilmu Pragmatik (Teori dan Penerapannya). Jakarta: Departemen Pendidikan dan Kebudayaan.

Pujiyanto. (2013). Iklan Layanan Masyarakat. Yogyakarta: Andi.

Sugiyono. (2012). Metode Penelitian Kuantitatif Kualitatif dan R\&D. Bandung: Alfabeta.

Yule, G. (2006). Pragmatics. Yogyakarta: Pustaka Pelajar. 
Contoh Foto Spanduk Iklan Warung

Bakso di Balikpapan, Khususnya Wilayah

Balikpapan Utara.
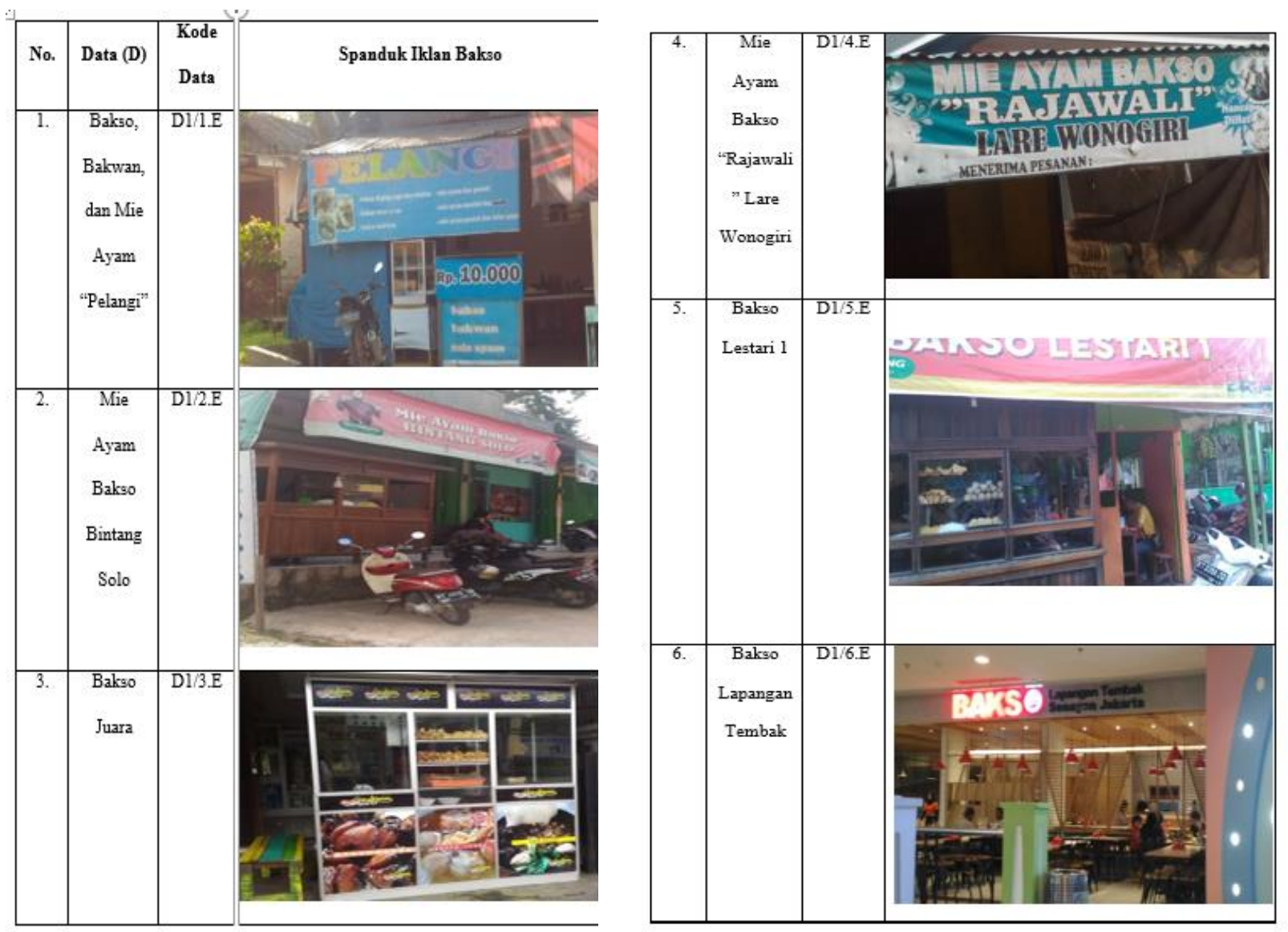